Research:

\title{
THE EFFECT OF ADDITION OF TAXPAYERS NUMBER, TAX AUDIT, TAX BILLING, AND TAXPAYERS COMPLIANCE TOWARD TAX REVENUE
}

\author{
By: \\ W A L U Y O \\ Lecturer at Mercubuana University Jakarta
}

\begin{abstract}
The purpose of this research is to examine the effect of addition of Taxpayer Number, Tax Audit, Tax Billing and Taxpayer Compliance toward tax revenue in simultaneously and partially. This research is done by using a multiple linear regression analysis model. The object of this research are tax office Tigaraksa for the period of 2009-2012. Data are collected from annual report of Tax Office Tigaraksa for the period of 2009-2012, consist of the number of additionaltaxpayer, number ofeffectivetax payers, the realization oftax assessments, the amount oftax arrears, number ofactual disbursement oftax arrears, tax revenue target,tax revenue, andthe reportednumber oftax returns. The results of this research are (1) increasing the number of taxpayers effect on tax revenue, (2) tax audit effect on tax revenue, (3) tax billing has no effect on tax revenue, (4) tax compliance effect on tax revenue, (5) the addition of the taxpayer, tax audits, tax billing and tax compliance simultaneously affect the tax revenue.
\end{abstract}

Keywords: Addition Taxpayer Number, Tax Audit, Tax Assessment, Tax Compliance, Tax Revenue

\section{INTRODUCTION}

Indonesia is a country of laws aimed toward improved the life of nation and state fair and prosperous, and ensure equal legal status for citizens. The lofty goal can only be realized through national development gradual, effective, and sustainable.

To drive national development, the government needs funds coming from. sources of foreign funds and domestic sources of funds. Source of state revenues or funds of the country with the most potential, namely taxes, therefore the tax as a source of state revenue to finance the construction.

The construction costs are financed by the public. that efforts to increase state revenue from tax sector is very important. Data growth contribution of tax revenue to total state revenue from 2009 to 2013 nationwide look like the following table:

Table 1

The Developments Contributions Tax Revenue (Billion Rupiah)

\begin{tabular}{|c|c|c|c|c|c|}
\hline Year & Tax Revenues & $\begin{array}{c}\text { Non Tax } \\
\text { Revenues }\end{array}$ & Grant & Amount & \% Tax Contribution \\
\hline$(1)$ & $(2)$ & $(3)$ & $(4)$ & $2+3+4=5$ & $2 \div 5=(6)$ \\
\hline 2009 & $619.922,2$ & $227.174,4$ & $1.666,6$ & $848.763,2$ & $73,03 \%$ \\
\hline 2010 & $723.306,7$ & $268.941,9$ & $3.023,0$ & $995.271,5$ & $72,68 \%$ \\
\hline 2011 & $873.874,0$ & $331,471,8$ & $5.253,9$ & $1.210 .599,6$ & $72,18 \%$ \\
\hline 2012 & $1.016 .237,3$ & $341.142,6$ & 825,1 & $1.358 .205,0$ & $74,82 \%$ \\
\hline 2013 & $1.192 .994,1$ & $332.195,4$ & $4.483,6$ & $1.529 .673,1$ & $77,99 \%$ \\
\hline
\end{tabular}

Source: Ministry of Finance of the Republic of Indonesia

Waluyo: The Effect of Addition of Taxpayers Number, Tax Audit, Tax Billing, and Taxpayers Compliance toward Tax Revenue 
From Table 1 it appears that the state revenue tax sectors that contributed the most, with a contribution of more than half of total state revenue. State revenue from tax sector tends to increase from year to year. To achieve the tax revenue target, the participation of communities in meeting their tax obligations based on tax regulations is expected.

Various efforts have been and are being made to increase the number of taxpayers, including through extension activities to the public through the mass media or otherwise, as well as cooperation with third parties, such as banks. With the increasing number of registered taxpayers are expected to increase state revenue in taxes.

As mandated by the tax laws as a consequence of the implementation of the selfassessment system in Indonesia, which required compliance testing fulfillment of tax obligations. Parties may be authorized testing meant that the Director General of Taxes. Implementation of the tax audit subsequently delegated authority to tax inspectors. Of expected tax audits of taxpayers will be more obedient in fulfilling their tax obligations. However, in practice it is not so easy to collect tax arrears source commencement of the tax audit. For the purposes of tax billingdiperluan various steps begin with the billing of passive and active until the auction on property taxpayers, even attempts hostages (gijzeling).

Law enforcement to taxpayers who do not pay off tax arrears within a predetermined time, among others by imposing measures tax billing has the legal power to force, in the form of a series of measures to get taxpayers to pay off the tax debt with a reprimand or warn, implement billing instantaneously and simultaneously, notify forced letter, the seizure and selling of goods that have been confiscated.

Efforts to increase tax revenues is optimal and implement an effective self-assessment system, need to be grown continuously awareness and taxpayer compliance. Tax compliance is a requirement that tax receipts can be improved, with more obedient to repay taxpayers and their tax reporting obligations, then the tax revenue will increase.

Based on the background of the problem can be formulated issues to be observed is whether increasing the number of taxpayers, tax audits, tax billing and tax compliance partially and simultaneously have an influence on tax revenue.

\section{STUDY LITERATURE}

\section{Tax Payers Registered}

Limitation of registered taxpayers by the Director General of Taxation Number KEP. $161 / \mathrm{PJ} / 2001$, the taxpayer who has been registered in the administration of the Tax Office and has been given a Taxpayer Identification Number is composed of 15 (fifteen) digits, namely 9 (nine) the first digit of the code Taxpayer and 6 (six) digits are the Code of Tax Administration. In accordance with the self-assessment system Taxpayers have an obligation to register with the Tax Office (KPP) or the Office of Information and Observation Potential Taxation (KP4) whose territory covers the residence or occupation of the taxpayer to be given a Taxpayer Identification Number (TIN). TIN registration can also be done via e-register, which is a way of TIN registration through electronic media on-line (Internet). TIN is a number given to the taxpayer as a means of identification or identity for each taxpayer in carrying out their rights and obligations in the field of taxation (Waluyo, 2011). Taxpayer granted Registration Certificate (SKT) no later than the next working day and TIN Card issued no later than three (3) working days after receipt of the request is complete. Please note that for the maintenance of public aforementioned TIN is free of charge.

According to Waluyo (2011), any tax documents as examples: Letter of tax payments (SSP), a tax invoice, Tax (SPT), must provide a TIN owned. Taxpayers who do not enroll to get a TIN sanctioned in accordance with the provisions of tax legislation. The number of taxpayers is meant the number of registered taxpayers in tax administration tax authorities. Efforts to increase the registered taxpayers do with the attempts to either the counseling or other means with the cooperation of various parties, such as banking or other business sectors.

\section{Tax Audit}

Tax audit principally aims to test compliance fulfillment of tax obligations or for other purposes. Definition of inspection as stated Waluyo (2011) as a series of activities to collect and process data, information, and / or evidence to be conducted objectively and professionally by a standard examination to test compliance fulfillment of tax obligations and / or for other purposes in 
order to implement the provisions of regulations tax laws. By understanding the tax audit encompasses search, collect and process data, and / or other information that comes from the taxpayer bookkeeping or from other sources which could be used to determine their tax liability. With the tax audit is intended to verify compliance fulfillment of tax obligations and other purposes. Coverage of other purposes, including tax audits in the provision of TIN to achieve the purpose of the examination, the examination should be done selectively to expect with these checks is expected to give a deterrent effect by increasing voluntary compliance by taxpayers.

The results of the examination set forth in the Notice of Examination (SPHP) submitted to the taxpayer in order to get a response. From the tax audit tax audit report prepared subsequently. Tax audit report is used as the basis for the issuance of tax assessment (SKP) may include tax assessment letters (SKPKB), an assessment letter on tax underpayment Supplement (SKPKBT) or more.

\section{Tax Billing}

Tax billing activities conducted tax authorities must be based on law. As a complement to support the implementation of tax laws in force since the reform of tax law in 1983 enactment of Law No. 19 of 1997 on the tax billing forced letter as last amended by law No. 19 of 2000.

Definition of Tax Billing is a series of actions in order to pay off debts Tax Insurers taxes and fees tax billing with reprimand or warn, billing implement immediately and simultaneously, notify Forced Letters, propose prevention, in the seizure, execute the hostage, selling goods that have been seized. Tax billing action in response to the fact that it still met the delinquent taxes as no tax debt redemption accordingly. Against tax arrears billing action is necessary to implement the tax law, which has the power to force. Tax billing laws forced letter regulate the provisions regarding the procedure for tax billing action in the form of billing immediately and at the same time, the implementation of forced letter, confiscation, prevention and / or hostage-taking and auctions.

\section{Taxpayer Compliance}

Tax compliance is defined as a state that has a tax compliance awareness in meeting tax obligations (Rustiyaningsih, 2011). Compliance and awareness of compliance and awareness fulfillment of tax obligations is reflected in situations of taxpayers to understand and try to understand all the provisions of the legislation taxation, filling out tax forms completely and clearly, calculate the amount of tax completely and clearly, and pay taxes owed right on time.

There are two kinds, namely compliance with formal compliance and adherence material. Formal compliance is a situation where a taxpayer formally meet tax obligations in accordance with the provisions of the tax laws.

Based on the Ministry of Finance No. 544 / KMK.04 / 2000, taxpayers in the category of tax compliance if it meets the following criteria:

a. Timely in submitting a notice to all types of taxes in the last two years.

b. Not have tax arrears for all types of taxes, unless it has obtained permission for installment or delay the payment of taxes.

c. Never convicted of carrying as referred to in Article 28 legislation general provisions and procedures of taxation (UU KUP), and in the case of the taxpayer never inspection, correction of the examination of the last for each type of tax payable at most $5 \%$.

d. A taxpayer whose financial statements for the last two years audited by a public accountant with an unqualified opinion or an opinion with exceptions.

Suhendra (2010) states to achieve the target of tax, need to be grown continuously awareness and compliance of tax payers to fulfill tax obligations according to applicable regulations. Given the awareness and taxpayer compliance are important factors for the increase in tax revenue, should intensively studied about the factors that influence taxpayer compliance.

\section{RESEARCH METHODS}

In a study using data from the taxpayer that the taxpayer is registered in the Tax Office Primary Tigaraksa years 2009 to 2012. The progress can be seen per month. The data used in the study of secondary data Addition taxpayer, the taxpayer Effectively, Realization issuance of tax 
assessment, target tax inspection, Total Tax Arrears, Actual Disbursement Tax Arrears, target of Revenue Realization of Revenue, and Total Tax (SPT) submitted in 2009 to 2012.

Testing the hypothesis in this study using multiple linear analysis because there are more than one independent variable. Linear equations used in this study are:

$$
Y=a+b_{1} X_{1}+b_{2} X_{2}+b_{3} X_{3}+b_{4} X_{4}+e
$$

Notes:

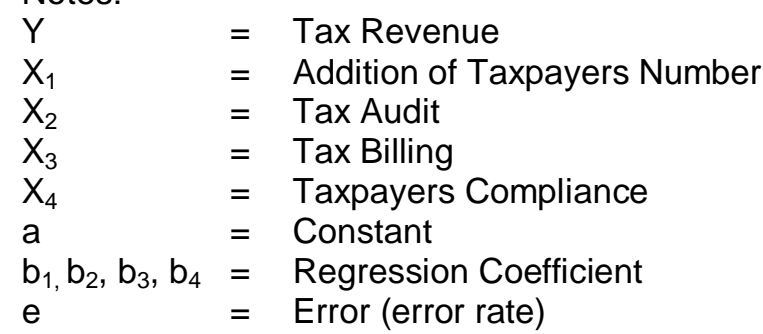

With the dependent variable $(\mathrm{Y})$ tax revenues and some independent variable $(\mathrm{X})$ and the measurement shown in the following table 2 :

Table 2

Operational Variables

\begin{tabular}{|c|c|c|c|c|}
\hline No & Variable & Concepts & Indicators & Scale \\
\hline 1 & Addition of Taxpayers $\left(\mathrm{X}_{1}\right)$ & $\begin{array}{l}\text { Registered taxpayer is a taxpayer in the } \\
\text { tax office administrative services and } \\
\text { has been given a TIN }\end{array}$ & $\begin{array}{l}\text { Comparison of the number of } \\
\text { registered taxpayers with an } \\
\text { effective amount of the taxpayer }\end{array}$ & Ratio \\
\hline 2 & Tax Audit $\left(\mathrm{X}_{2}\right)$ & $\begin{array}{l}\text { A tax audit is an examination conducted } \\
\text { in an appropriate year of screening } \\
\text { policies }\end{array}$ & $\begin{array}{l}\text { Comparison of the realization of } \\
\text { the provisions targeted } \\
\text { examination results examination }\end{array}$ & Ratio \\
\hline 3 & Tax Billing $\left(X_{3}\right)$ & $\begin{array}{l}\text { Tax billing is a series of tax billing action } \\
\text { so that the insurer pay off tax debts and } \\
\text { tax billing fee }\end{array}$ & $\begin{array}{l}\text { Comparison of actual } \\
\text { disbursement of tax arrears to } \\
\text { the amount of tax arrears }\end{array}$ & Ratio \\
\hline 4 & Taxpayers Compliance $\left(\mathrm{X}_{4}\right)$ & $\begin{array}{l}\text { Tax compliance is a state of } \\
\text { consciousness taxpayer has to fulfill tax } \\
\text { obligations }\end{array}$ & $\begin{array}{l}\text { Comparison of the number of tax } \\
\text { returns submitted by the amount } \\
\text { of tax arrears }\end{array}$ & Ratio \\
\hline 5 & Tax Revenues (Y) & $\begin{array}{l}\text { Tax revenue is total tax revenue in the } \\
\text { tax year }\end{array}$ & $\begin{array}{l}\text { Comparison of tax revenue with } \\
\text { the tax revenue target }\end{array}$ & Ratio \\
\hline
\end{tabular}

\section{DISCUSSION AND ANALYSIS}

Normality test results by performing a statistical test by using non-parametric statistical test of Kolmogorov-Smirnov (K-S) according to the following table 3:

Table 3

Result of One-Sample Kolmogorov-Smirnov (K-S) Test

\begin{tabular}{|ll|r|}
\hline & & \multicolumn{2}{|c|}{ Unstandardized Residual } \\
\hline$N$ & & 48 \\
Normal & Mean &, 00000000 \\
Parametersa,b & Std. Deviation &, 14049809 \\
Most & Absolute &, 105 \\
Extreme $\quad$ Positive &, 105 \\
Differences Negative & -089 \\
Kolmogorov-Smirnov Z &, 724 \\
Asymp. Sig. (2-tailed) &, 670 \\
\hline a. $\quad$ Test distribution is Normal & \\
b. Calculated from data. & \\
\hline
\end{tabular}

Waluyo: The Effect of Addition of Taxpayers Number, Tax Audit, Tax Billing, and Taxpayers Compliance toward Tax Revenue

Page: 40 
From Table 3 it can be concluded that the value of the Kolmogorov-Smirnov, the significant value of 0.670 or greater than 0.05 , indicating that the data in this study are normally distributed. Here are the results of data processing used in the study found the value of R as follows on table 4:

Tabel 4

Result of Coefficient Correlation Test

Model Summaryb

\begin{tabular}{|c|c|c|c|c|c|c|}
\hline \multirow[t]{2}{*}{ Model } & \multirow[t]{2}{*}{$\mathrm{R}$} & \multirow[t]{2}{*}{ R Square } & \multirow{2}{*}{$\begin{array}{l}\text { Adjusted R } \\
\text { Square }\end{array}$} & \multirow{2}{*}{$\begin{array}{l}\text { Std. Error of the } \\
\text { Estimate }\end{array}$} & \multicolumn{2}{|c|}{ Change Statistics } \\
\hline & & & & & $\begin{array}{l}\text { R Square } \\
\text { Change }\end{array}$ & F Change \\
\hline 1 & ,538a & ,289 & ,223 & ,14688760 & ,289 & 4,369 \\
\hline
\end{tabular}

From the test results obtained correlation coefficient $\mathrm{R}$ positive value that is equal to 0.538 . From $\mathrm{R}$ value obtained showed that the relationship between the dependent and independent variables positively correlated or there is a direct relationship between the dependent and independent variables. The coefficient of determination (R2) to measure how far the ability of the model to explain variations in the dependent variable. The coefficient of determination appears below:

Table 5

Results of Coefficient Determination Test

Model Summaryb

\begin{tabular}{|c|c|c|c|c|c|c|}
\hline \multirow[t]{2}{*}{ Model } & \multirow[t]{2}{*}{$\mathrm{R}$} & \multirow[t]{2}{*}{ R Square } & \multirow{2}{*}{$\begin{array}{l}\text { Adjusted R } \\
\text { Square }\end{array}$} & \multirow{2}{*}{$\begin{array}{l}\text { Std. Error of the } \\
\text { Estimate }\end{array}$} & \multicolumn{2}{|c|}{ Change Statistics } \\
\hline & & & & & $\begin{array}{l}\text { R Square } \\
\text { Change }\end{array}$ & F Change \\
\hline 1 &, $538^{a}$ & ,289 & ,223 & , 14688760 & ,289 & 4,369 \\
\hline
\end{tabular}

Value Adjusted $\mathrm{R}$ Square on the tables of 0.223 indicating that $22.3 \%$ dependent variable, can be explained by the variation of the independent variable, ie increasing the number of taxpayers, tax audits, tax collection and tax compliance.

Statistics t test showed how far the influence of the independent variables individually in explaining the variation of the dependent variable (Ghozali, 2011). Statistics t test results as follows:

Table 6

Coefficients $^{\mathrm{a}}$

\begin{tabular}{|c|c|c|c|c|c|c|}
\hline \multirow{2}{*}{\multicolumn{2}{|c|}{ Model }} & \multicolumn{2}{|c|}{ Unstandardized Coefficients } & \multirow{2}{*}{$\begin{array}{c}\text { Standardized } \\
\text { Coefficients } \\
\text { Beta }\end{array}$} & \multirow[t]{2}{*}{$\mathrm{T}$} & \multirow[t]{2}{*}{ Sig. } \\
\hline & & B & Std. Error & & & \\
\hline \multirow{5}{*}{1} & (Constant) & 1,271 &, 077 & & 16,396 &, 000 \\
\hline & $\mathrm{X} 1$ &, 591 & ,293 & ,364 & 2,018 & ,050 \\
\hline & $\mathrm{X} 2$ & ,053 & ,020 & 348 & 2,694 & ,010 \\
\hline & X3 &, 760 & ,474 & ,209 & 1,605 & ,116 \\
\hline & $\mathrm{X} 4$ & $-1,768$ & ,655 &,- 488 & $-2,701$ & ,010 \\
\hline
\end{tabular}

a. Dependent Variable: Tax Revenues

Based on Table 6, the results obtained regression equation in this study, such as:

$$
Y=1,271+0,591 \times 1+0,053 \times 2+0,760 \times 3-1,768 \times 4+e
$$

Waluyo: The Effect of Addition of Taxpayers Number, Tax Audit, Tax Billing, and Taxpayers Compliance toward Tax Revenue 
Based on Test Results Statistics t, can be explained as follows:

\section{Hypothesis 1 : Addition of tax payers number effect on tax revenue}

The addition of a variable amount of the taxpayer. The coefficient is positive, there is a positive effect of the addition of the number of taxpayers with tax revenue. The results are consistent with research conducted Syahab (2008) which concluded that the increase in the number of taxpayers is partially significant effect on the corporate income tax receipts.

\section{Hypothesis 2 : Tax audit effect on tax revenue}

Obtained a regression coefficient of 0.053 for the variable tax audit. The coefficient is positive, meaning a positive influence between tax audits with tax revenue. Test results show the statistics t-value of 0.01 or less than 0.05 . The results of this study mean $\mathrm{H} 2$ received, so it can be concluded that the tax audit has a significant effect on tax revenues. The results are consistent with research conducted by Sari and Afriyanti (2012) which concluded that the partial tax audit significant effect on tax revenue.

\section{Hypothesis 3 : Tax billing effect on tax revenue.}

The correlation coefficient of 0.760 for the variable tax collection. The coefficient is positive, it means there is a positive influence between the tax collection by tax revenue. Statistics t test results showed $t$ value of 0.116 or greater than 0.05 . The results of this study mean $\mathrm{H} 3$ is rejected, so it can be concluded that the tax collection does not have a significant effect on the tax revenue is seen from the disbursement of tax arrears. The results of this study are not consistent with research conducted by Syahab and Gisijanto (2008) which concluded that the tax billing significant impact on tax revenue.

\section{Hypothesis 4 : Compliance taxpayer effect on tax revenue.}

Obtained a regression coefficient of -1.768 for the variable tax compliance. The coefficient is negative, meaning a negative influence between the taxpayer compliance with tax revenue. Test results show the statistics $t \mathrm{t}$ value of 0.01 or less than 0.05 . The results of this study mean $\mathrm{H} 4$ is accepted, that tax compliance has a significant impact on the tax revenue. The results are consistent with research conducted by Suhendra (2010), which showed that the level of tax compliance as measured by the amount of the Annual Tax Return (SPT) which delivered a significant effect on the increase in corporate income tax revenue.

F statistics test performed with a significance level of $\alpha=0.05$, the test results are as follows:

Table 7

Result of Statistic F Test

\begin{tabular}{|ll|r|r|r|r|r|}
\hline Model & & Sum of Squares & df & Mean Square & F & \multicolumn{1}{c|}{ Sig. } \\
\hline \multirow{4}{*}{1} & Regression &, 377 & 4 &, 094 & 4,369 &, 005 \\
& Residual &, 928 & 43 &, 022 & & \\
& Total & 1,305 & 47 & & & \\
\hline
\end{tabular}

a. Dependent Variabel: Tax Revenue

b. Predictors: (Constant, addition ogtak number, Addition of Tax Number,

c. Compliance of Tax Payers Kepatuhan WP)

Based on the results of statistics $F$ test shown in Table 7 can be explained as follows:

Hypothesis 5: Added Tax Payers, Tax Audit, Tax Collection and Taxpayer Compliance simultaneously affect the tax revenue.

Provided that the $F$ value of 4.369 with a significance level of 0.005 or less than 0.05 . The results showed $\mathrm{H} 5$ acceptable and it can be concluded that together all independent variables which consists of increasing the number of taxpayers, tax audits, tax billing and compliance of tax payerssimultaneously significant effect on tax revenue. This study is in line with research Syahab (2008) which states that the tax inspection, Taxpayer Compliance, Registered Added Tax Payers and Tax Billing influence simultaneously to tax revenues. 


\section{CONCLUSION}

The conclusions derived from the results of this study as follows:

1. Increasing the number of registered taxpayers have an impact on tax revenue. This is shown by the results of the test statistic $t$ with regression coefficient of $0.591 \mathrm{t}$-value of 2.018 with a significance level of 0.05 , it can be concluded that the increase in the number of taxpayers have a significant effect on tax revenues. It should be observed that the increase in the number of taxpayers dominated by potential taxpayers, thus appears in an effort to dig the potential of tax by the Tax Office.

2. Tax Inspection significant effect on Tax Revenue. This is shown by the results of the test statistic $t$ with regression coefficient of 0.053 , $t$ value of 2.694 with a significance level of 0.01 or less than 0.05 . This condition is very supportive that tax inspections are still required, although very selectively but as power carrying capacity for achieving the target of tax revenue.

3. Tax Billing has no effect on tax revenue. This is shown by the results of the test statistic $t$ with regression coefficient of $0.760, t$ value of 1.605 with a significance level of 0.116 or greater than 0.05 . T statistical test results can be seen that there is no influence of tax collection to tax revenues. Many obstacles that may occur resulting in tax collection it had no effect, may not be available database of accurate taxpayer or the amount billed to the nominal relative small.

4. Compliance taxpayers have an impact on tax revenue. This is indicated by the results of the test statistic $t$ with a significance level of 0.01 or less than 0.05 . With the condition of the taxpayer effect on tax revenue, then the taxpayer is conditioned unconscious in fulfilling the taxation obligation. But when the taxpayer is abiding taxpayers with small nominal tax payments as well, the effect is not significant.

5. Addition of Tax Payers, Tax Audit, Tax Collection and Tax Compliance jointly affect the Tax Revenue. This is demonstrated by a statistical test $F$ with $F$ value of 4.369 with a significance level of 0.005 or less than 0.05 .

\section{REFERENCES}

Ghozali, Imam. Aplikasi Analisis Multivariate dengan Program IBM SPSS 19. Semarang: Badan Penerbit Universitas Diponegoro. 2011.

Lind, Douglas A dkk.. Statistical Techniques in Business and Economics With Global Data Sets. New York: Mc Graw-Hill//rwin. 2008.

Listyaningstyas, Ellya Florentin. "Efektivitas Pelaksanaan Pemeriksaan dalam Rangka Meningkatkan Penerimaan Negara dari Sektor Pajak (Studi Kasus di KPP Tulungagung)" Jurnal Akuntansi UNESA. No. 1. Vol. 1. 2012

Rustiyaningsih, Sri. "Faktor-Faktor yang Mempengaruhi Kepatuhan Wajib Pajak". No. 02, ISSN 0854-1981. Juli 2011. HIm. 44-54.

Saputra, Putu Mahardika Adidan Dina Fitriani W. "Analisa Faktor-Faktor yang Mempengaruhi Jumlah Penerimaan Pajak Penghasilan Orang Pribadi (Studi Kasus di Wilayah Kerja Kantor Pelayanan Pajak Batu". Journal of Indonesian Applied Economics. Vol. 3, No. 2. Oktober 2009. HIm. 135-149.

Sari, Maria M Ratnadan Ni Nyoman Afriyanti. "Pengaruh Kepatuhan Wajib Pajak dan Pemeriksaan Pajak terhadap Penerimaan PPh Pasal 25/29 Wajib Pajak Badan pada KPP Pratama Denpasar Timur". Jurnal Ilmiah Akuntansi dan Bisnis. Vol. 7, No. 2. Januari 2012. HIm. 121.

Sekaran, Uma dan Roger Bougie. Research Methods for Business. New York: John Wiley and Sons, Ltd, Publication. 2010.

Waluyo: The Effect of Addition of Taxpayers Number, Tax Audit, Tax Billing, and Taxpayers Compliance toward Tax Revenue 
Suhendra, EuphrasiaSusy. "Pengaruh Tingkat Kepatuhan Wajib Pajak Badan terhadap Peningkatan Penerimaan Pajak Penghasilan Badan". Jurnal Ekonomi Bisnis. No.1, Vol.15. April 2010. HIm. 58-65.

Sukirman. "Pengaruh Manajemen Pemeriksaan Pajak terhadap Penerimaan Pajak". Analisis Manajemen. Vol. 5, No. 1. Juli 2011. HIm. 87-101.

Syahab, Zakiah M. "Analisis Pengaruh Pemeriksaan Pajak, Kepatuhan Wajib Pajak, dan Penambahan Jumlah Wajib Pajak Terdaftar terhadap Penerimaan Pajak Penghasilan Badan di Lingkungan Kanwil DJP Jakarta Selatan". E-journal Ekonomi. September 2012. HIm. 1-16.

Syahab, Zakiah M dan Hantoro Arief Gisijanto. "Pengaruh Penagihan Pajak dan Surat Paksa Pajak terhadap Penerimaan Pajak Penghasilan Badan". Jurnal Ekonomi Bisnis. No.2, Vol.13 Agustus 2008. HIm. 137-152.

Vegirawati, Titin. "Hubungan Antara Penerbitan Surat Tagihan Pajak dengan Penerimaan Pajak Pada KPP Pratama llir Timur Palembang". Jurnal Ekonomi Dan Informasi Akuntansi. Vol. 1. No. 3. September 2011. HIm. 266-274.

Waluyo. Perpajakan Indonesia. Buku 1, Edisi 10. Jakarta: Salemba Empat. 2011.

. Perpajakan Indonesia. Buku 1, Edisi 9. Jakarta: Salemba Empat. 2010.

\section{Law and Regulation}

Direktorat Jenderal Pajak. Surat Edaran Nomor SE-06/PJ.7/2004. "Pemeriksaan Sederhana Lapangan dalam Rangka Ekstensifikasi Wajib Pajak". dalam http://www.ortax.org/ortax/?mod=aturan\&page=show\&id=911.

. Keputusan Direktur Jenderal Pajak Nomor KEP-161/PJ./2001. “Jangka Waktu Pendaftaran dan Pelaporan Kegiatan Usaha, Tata Cara Pendaftaran dan Penghapusan Nomor Pokok Wajib Pajak, Serta Pengukuhan dan Pencabutan Pengukuhan Pengusaha Kena Pajak". dalam http://www.ortax.org/ortax/?mod=aturan\&page=show\&id=1202.

. Undang-undang Republik Indonesia Nomor 28 Tahun 2007. "Perubahan Ketiga Atas Undang-undang Nomor 6 tahun 1983 Tentang Ketentuan Umum dan Tata Cara Perpajakan". dalam http://www.ortax.org/ortax/?mod=aturan\&page=show\&id=1276.

Undang-Undang Republik Indonesia Nomor 36 Tahun 2008. "Perubahan Keempat Atas Undang-Undang Nomor 7 Tahun 1983 Tentang Pajak Penghasilan". dalam http://www.dikti.go.id/files/atur/uang/UU36-2008.pdf. 